Onkologie 1991;14(suppl 1):2

\title{
Inhalt, Vol. 14, Supplement 1, 1991
}

\section{ONKOLOCIE}

Internationale Zedtschrrift für Krebsf orschung und -behandlung

Supplement 1 zu Band 14, August 1991

Inhalt

Contents

Übersicht iiber derzeitige Konzepte in der Psycho-neuroimmunologie*

Kappauf, H.W 10

Interaktionen zwischen Immunsystem und zentralem

Nervensystem (I)*

Fischer, J 14

Interaktionen zwischen Immunfunktionen und zentralem Nervensystem (II)*

Yirmiya, $\mathrm{R} \quad 16$

Streßeffekte auf das Immunsystem*

Schulz, K.H 19

Auswirkungen von Verlust und Depression auf Immunmechanismen und Onkogenese*

Beutel, M 30

Spontanremissionen und unerwartet günstiger Verlauf*

Kappauf, H.W 32

Therapeutische Schlußfolgerungen aus den psychoneuroimmunologischen

Forschungsergebnissen*

Speidel,H 36

Interventionsmethoden*

Köhle, K 39

Empfehlungen für die Umsetzung der Psychoneuroimmunologie-Forschungsergebnisse in die onkologische Praxis*

Kappauf, H.W., Büntig, W.E 42

Impressum 1

Inhaltsverzeichnis 2

Vorwort 3

Die Deutsche Krebshilfe 4

Einführung 7

Hinweise für Autoren 46

* Die Beiträge sind Zusammenfassungen der neuen gleichnamigen Konferenzsitzungen. Die Autoren beziehen sich auf die jeweiligen Expertenvorträge und Diskussionsbeiträge.

Survey of Current Concepts in Psychoneuroimmunology*

Kappauf, H.W 10

Interactions of Immune and Central Nerve System

Processes (I)*

Fischer, J 14 
Interactions of Immune and Central Nervous System Processes (II)*

Yirmiya, R 16

Impact of Stress on Immune Mechanisms and Oncogenesis*

Schulz, K.H 19

Impact of Loss and Depression on Immune Mechanisms and Oncogenesis*

Beutel, $M \quad 30$

Unexpected Benign Course and Spontaneous Recovery in Malignant Disease*

Kappauf, H.W 32

Therapeutic Consequences of Psychoneuroimmunology Research Data*

Speidel,H 36

Methods of Interventions*

Köhle, K 39

Recommendations for Clinical Applications of Psychoneuroimmunology in Relation to Cancer* Kappauf, H.W., Büntig, W.E 42

Imprint1

Contents 2

Preface 3

Die Deutsche Krebshilfe 4

Introduction 7

Instructions to Authors 46

* These articles are summaries of the new conference meetings of the same name. The authors refer to the lectures by the experts and following discussions.

Bibliographischer Hinweis: Inhaltsverzeichnisse dieser Zeitschrift erscheinen regelmäßig in current contents ${ }^{\circledR}$ sowie in anderen bibliographischen Diensten. 